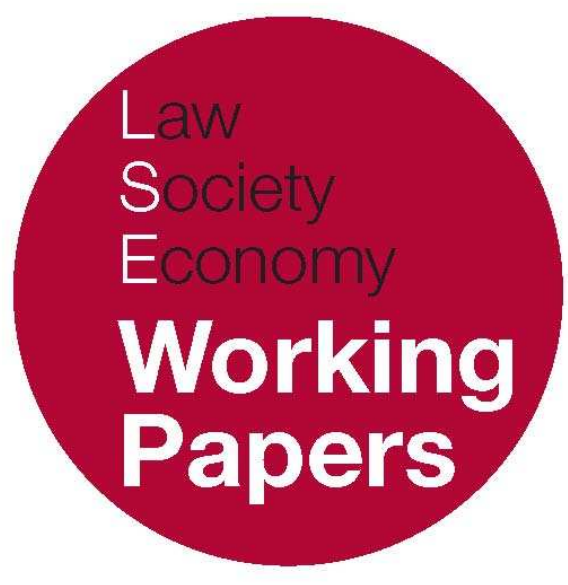

\title{
Forms and Paradoxes of Principles Based Regulation
}

\author{
Julia Black \\ LSE Law, Society and Economy Working Papers 13/2008 \\ London School of Economics and Political Science \\ Law Department
}

\begin{abstract}
This paper can be downloaded without charge from LSE Law, Society and Economy Working Papers at: www.lse.ac.uk/collections/law/wps/wps.htm and the Social Sciences Research Network electronic library at: http:/ / ssrn.com/abstract=1267722.

(C) Julia Black. Users may download and/or print one copy to facilitate their private study or for non-commercial research. Users may not engage in further distribution of this material or use it for any profit-making activities or any other form of commercial gain.
\end{abstract}




\title{
Forms and Paradoxes of Principles Based Regulation
}

\author{
Julia Black ${ }^{*}$
}

\begin{abstract}
Principles-based regulation is high on the regulatory agenda in a number of regulatory domains, most particularly financial regulation. Its supporters argue that it provides a flexible regulatory regime which can facilitate innovation; its detractors argue that it is simply lax regulation. This article explores the political rhetoric surrounding principles-based regulation. It identifies four forms of principles-based regulation: formal, substantive, full and polycentric principles-based regulation. It also identifies and explores seven paradoxes which principles-based regulation may encounter in its various forms. These relate to interpretation, communication, compliance, enforcement, internal management, ethics, and above all trust. $\mathrm{PBR}$, in its full form, can provide an effective, durable, resilient and goal based regulatory regime; but at the same time its paradoxical nature means that it is vulnerable in many respects. Unfortunately for the detractors of principles-based regulation, many of these paradoxes are not necessarily avoided by using detailed rules instead of principles. Rather their resolution lies in trust. Yet, it is argued, trust is the ultimate paradox. Principles-based regulation can help to create trust, but the core elements of that trust have to already exist if principles-based regulation is ever to operate effectively, if indeed at all.
\end{abstract}

\section{INTRODUCTION}

Only a year ago it seemed that 'principles-based' regulation was the answer that all policy makers and those running financial institutions had been looking for. ${ }^{1}$ The

\footnotetext{
* Professor of Law and Research Associate, Centre for the Analysis of Risk and Regulation, London School of Economics and Political Science. I am grateful to the participants in the workshops on PBR and compliance and legal risk management run by the LSE Law and Financial Markets Project in conjunction with Herbert Smith LLP, and funded by Herbert Smith LLP in February and March 2007 and March 2008 for discussions which have informed many aspects of this paper. I am also grateful to Joanna Benjamin, Sharon Gilad and David Kershaw for providing insightful comments. Responsibility for all views, errors and omissions remains my own. Any comments can be addressed to me at j.black@1se.ac.uk. This paper will appear in Capital Markets Law Journal 3(4) 2008.

${ }^{1}$ FSA, Principles Based Regulation: Focusing on the Outcomes that Matter (FSA, April 2007) (hereafter FSA, PBR); for a representation of industry views, see the report of the British Bankers' Association Annual
} 
Financial Services Authority had just issued its paper on how it would operationalise its approach to principles based regulation and the challenges that the FSA, firms and their advisers would have to meet to make the approach work. ${ }^{2}$ The EU Commission was trumpeting the benefits of a principles based approach, ${ }^{3}$ although the FSA was arguing the EU still had a long way to go in this direction. ${ }^{4}$ Politicians in the US were looking askance at the impact of Sarbanes-Oxley and extolling the virtues of principles based regulation. A report by McKinsey \& Co, commissioned by the Mayor of New York, Michael Bloomberg and Senator Charles Schumer, recommended that the US adopt a 'two-tier' principles based approach, developing a set of principles to guide the regulators in performing their roles and a set of principles to guide firms. ${ }^{5}$ US Treasury Secretary Hank Paulson echoed these recommendations in his suggestion that the US should move to a UK style approach to regulating capital markets, relying on principles rather than detailed rules. ${ }^{6}$ This has now been formalized in the US Treasury's Blweprint for a Modernized Financial Regulatory Structure. ${ }^{7}$ Combined with parallel debates on the role of principles in accounting regulation ${ }^{8}$ and tax law in particular, ${ }^{9}$ the issue of 'principles based regulation' was, and to an extent still is, high on the regulatory agenda in a number of regulatory domains, ranging from the familiar ones of tax,

Conference, 4th July 2007 available at http://www.bba.org.uk/bba/jsp/polopoly.jsp?d=145\&a=9936 (accessed 19th June 2008).

2 FSA, PBR.

3 Commissioner McCreevy, 'Capital Market Place' Wall Street Journal $5^{\text {th }}$ March 2007, available at http://www.eurunion.org/newsweb/EUInMedia/cmcWSJoped030507.htm; see also his speech to the European Parliament ECON Committee (Committee on Economic and Monetary Affairs), Brussels, 11 September 2007: "We believe that a "light touch", principle-based regulation is the best approach for the financial sector.' Available at http://europa.eu/rapid/pressReleasesAction.do? reference=SPEECH/07/ $520 \&$ format $=$ HTML\&aged $=1 \&$ language $=\mathrm{EN} \&$ guiLanguage $=$ en .

${ }^{4} \mathrm{FSA}, \mathrm{PBR}$ at $20-21$.

${ }^{5}$ McKinsey \& Co, Sustaining New York's and the US's Global Financial Services Leadership (2007), available at http://www.senate.gov/ schumer/SchumerWebsite/pressroom/special_reports/2007/NY_REPORT $\% 20 \_$FINAL.pdf.

6 Accounting Today $16^{\text {th }}$ April 2007.

7 Available at http://www.treas.gov/press/releases/reports/Blueprint.pdf

${ }^{8}$ See eg the US Financial Accounting Standards Board, Proposal - Principles Based Approach to US Standard Setting (File Reference No 1125-003, January 2003) available at http://www.fasb.org/proposals/ principles-based_approach.pdf.

9 The issue of whether tax law should move to a more principles-based approach has been actively debated for some time: see eg J.F. Avery Jones in 'Tax Law: Rules or Principles?' (1996) 38 British Tax Review 580; J. Braithwaite, 'Making Tax Law More Certain: a Theory' (2003) 31 Australian Business Law Review 72; D. Weisbach, 'Formalism in the Tax Law' (1999) 66 U.Chi.L.R. 860; J.Freedman, 'Defining Taxpayer Responsibility: In Support of a General Anti-Avoidance Principle' [2004] British Tax Review 332; S. Picciotto, 'Constructing Compliance: Game-playing, Tax Law and the Regulatory State' (2007) 29 Law and Policy 11; J. Freedman, 'Interpreting Tax Statutes: Tax Avoidance and the Intention of Parliament' (2007) 123 Law Quarterly Review 53. Principles-based drafting of tax law is the subject of an experiment in Australia; see G. Pinder, The Coherent Principles Approach to Tax Law Design (Australian Treasury, 2005), http://tofa.treasury.gov.au/content/downloads/coherent principles.pdf. 
takeovers, accounting and corporate governance regulation ${ }^{10}$ to the decommissioning of nuclear power stations. ${ }^{11}$

A year on, the credit crisis has moved the debate on principles based regulation out of the political spotlight, and indeed it has become peripheral to the immediate fire-fighting tasks of dealing with the acute financial crisis. But once that immediate task has been addressed, at least in the short term, the debate will turn again as to how best to regulate the financial markets. Principles-based regulation is bound once again to come onto the agenda, though the political context is likely to be very different from that prevailing just a year ago. The arguments in favour of principles based regulation are familiar. For firms, principles-based regulation can provide flexibility, facilitate innovation and so enhance competitiveness. Principles based regulation can be beneficial for regulators too: it can provide them with flexibility, facilitate regulatory innovation in the methods of supervision adopted; enable the regulatory regime to have some durability in a rapidly changing market environment; and enhance regulatory competitiveness. Other stakeholders can benefit from the improved conduct of firms as they focus more on improving substantive compliance and achieving outcomes and less on simply following procedures, box-ticking or on working out how to avoid the rule in substance whilst complying with its form: 'creative compliance'.

But, as we all know, life is never that simple, and in the wake of the credit crunch and Northern Rock, both principles based regulation and its UK regulatory counterpart, risk based regulation, have lost their allure, at least for some. ${ }^{12}$ Principles based regulation is criticized, particularly by lawyers, for failing to provide certainty and predictability, and for creating a regulatory regime in which regulators can act retrospectively. Principles are also criticized for allowing firms to 'backslide', and get away with the minimum level of conduct possible; and thus for providing inadequate protection to consumers and others. ${ }^{13}$

Principles based regulation has the potential to live up to the expectations of both its supporters and its critics. Whether it does depends on how it is implemented and on the institutional context which surrounds it. Critically, that institutional context has to be characterized by the presence of a high degree of mutual trust between participants within the regulatory regime. Principles may be

\footnotetext{
${ }^{10}$ DTI, Promoting Competitiveness: The UK Approach to EU Company Law and Corporate Governance (HMSO, undated), 6.

11 DBERR, Consultation on Funded Decommissioning Programme Guidance for New Nuclear Power Stations, presentation March 2008, available at http://www.berr.gov.uk/files/file46258.pdf (accessed 13th June 2008).

12 The Treasury Select Committee's report, Run on the Rock (Fifth Report 2007-8) severely criticized the FSA's operation of its risk based model, stating there had been a 'substantial failure of regulation' (para. 42), and that the FSA appeared to have 'systematically failed in its duty as a regulator to ensure that Northern Rock would not pose such a systemic risk' (para. 66).

${ }^{13}$ For example in the US the National Association of Insurance Commissioners blamed the Savings and Loans crisis on a move to principles based regulation, and has argued that where principles are applied in the courts, their ambiguities may be argued to the disadvantage of consumers and firms consumers may lose out: NAIC Response to Treas-DO-2007-0018 28 th November 2007, available at http://www.naic.org/documents/topics_federal_regulator_treasury_response_0711.pdf.
} 
necessary for principles based regulation (PBR) to be work in some form, but they are by no means sufficient. ${ }^{14}$ If principles based regulation in its full form (explained below) is to be effective, there needs to be close engagement between regulator and regulatee based on mutual trust; firms need to be concerned to go beyond minimal compliance with the regulatory requirements; outcomes and goals have to be clearly communicated by the regulator, the enforcement regime has to be predictable, and, most relevant for the US, the culture of litigation needs to be restrained. ${ }^{15}$

However, it is possible, and indeed likely, that even if these institutional preconditions are met, that PBR lives up to the expectations of both its detractors and its supporters, but in different parts of the regulatory regime. The benefits and drawbacks of PBR are not a zero-sum game; they may be simultaneously realized in different parts of the regulatory regime. This is partly because how one experiences PBR depends in part on where one sits in the regime: in compliance, in senior management, in the regulator, as an investor. But it is also, and perhaps more fundamentally, because there are a number of paradoxes of PBR. These paradoxes may be embedded within it; or they may come from the broader institutional context in which the PBR may be situated.

This article identifies seven key paradoxes of PBR in its various forms. These paradoxes relate in part to the nature of principles, and in part to the way that PBR is put into practice by regulators, regulated firms and others. The first, the interpretive paradox, is that although principles may facilitate interpretation of the regulatory objectives and responsibilities of firms more clearly for some, they can also impede interpretation for others, particularly lawyers. The second, the communicative paradox, is that although principles can facilitate communication by expressing the purpose of the rule, they can hinder communication for a number of reasons. The third paradox concerns compliance. It is that although PBR can provide flexibility to firms, allowing them to innovate in the ways that they comply, in practice a lack of certainty as to what enforcers will accept as compliance can lead firms to adopt quite conservative behaviour. ${ }^{16}$ The fourth paradox concerns supervision and enforcement. Although principles can provide flexibility to regulators in the way that they monitor and enforce the regulatory requirements, and can save them from their own lack of foresight in the way detailed rules cannot, regulators too can in practice develop quite conservative interpretations and practices, particularly where there is little political support for tough enforcement action. The fifth paradox relates to internal management. It is that although principles based regulation in its substantive form relies in part on internal compliance systems and can give them scope for expansion and innovation, it can also overload them. Compliance systems can be empowered

14 J. Black, M. Hopper and C. Band, 'Making a Success of Principles Based Regulation' (2007) 1 (3) Law and Financial Markets Review 191.

${ }_{15}$ On the latter point see the discussion in both the McKinsey report and the Blueprint.

16 This is Schwarz's principles paradox: S.L. Schwarcz, 'The "Principles" Paradox' (March 1, 2008), Duke

Law School Legal Studies Paper No. 205 Available at SSRN: http://ssrn.com/abstract=1121454. 
under PBR, but only if they are strong already. Research suggests that compliance systems are the least developed aspect of financial institutions' internal systems and controls, and are not necessarily in a position to fill the role that PBR gives them. The sixth, ethical paradox is that although principles based regulation can facilitate the development of an ethical compliance culture, it also requires firms to take a risk-based approach to compliance which can stultify the development of such a culture. The final, ultimate paradox relates to trust. PBR can lead to the development of the type of relationship invoked by the Utopian vision, of responsibility, mutuality and trust, but these are the very elements of the regulatory relationships that have to be present for it to operate at all.

Exploring the complexities of PBR through these paradoxes, it is suggested, can help move the debate beyond that of setting out PBR's advantages and disadvantages. Not only have the pros and cons of PBR been well aired, there is a tendency to see them in too stark terms: PBR as either one or the other, whereas in practice it may be both at the same time. Moreover drawing out the paradoxes of PBR illustrates the complexities of PBR. Some of these paradoxes can be enhanced or mitigated by the institutional context; others are an inherent feature which those who advocate or work in a PBR regime need to recognize in order either to exploit the tensions that are created, where this is positive, or to minimize them.

However, before we can explore the paradoxes, we need to be clear what we mean by PBR. PBR is a complex form of regulation and it takes different forms in different contexts, countries and regulatory domains (tax, securities, accounting, health). The article identifies four forms of PBR: formal PBR, substantive PBR, full PBR and polycentric PBR. PBR can be formal, in the sense that there are principles in the rule books (including legislation, codes of practice and so on) but it may not be substantive. In contrast, a regime may have some of the operational characteristics of a PBR regime, but not have principles in the rule books. Where it is both, it is described as full PBR. Polycentric PBR is full PBR with the additional element that it is characterized by the enrolment of others, beyond regulators and firms, in the elaboration of the meaning and application of principles. The paradoxes can relate to the formal and / or the substantive element; and polycentricity can introduce a further set of paradoxes. These labels are not intended to have normative overtones; they are simply useful shorthand descriptions.

The particular context in which these issues will be discussed is the UK Financial Services Authority's (FSA's) recent move to a 'more principles-based approach' to regulation. The FSA is not the only financial regulator to emphasis the role of principles in its regulatory regime. Despite the common perception of US securities regulation as rule-bound, the Commodities and Futures Trading Commission has long operated a principles-based approach, and indeed one of the grounds of its resistance to the US Treasury's proposal that it be merged with the SEC was that it would have to sacrifice this at the altar of the SEC's rule-based 
approach. ${ }^{17}$ In Canada, the British Columbia Securities Commission (BCSC) had re-written its securities law into plain language, using a principles-based approach, in 2004. ${ }^{18}$ The Bill received Royal Assent but has never been brought into force, pending the outcome of the endless debates on the reform of Canada's system of securities regulation. ${ }^{19}$ Notwithstanding this setback, the BCSC has changed its approach to implementation - delivering principles-based regulation but without the principles.

Thus despite its prominence in recent debates, the FSA is by no means the only financial regulator which is regulating the 'principles-based way' and financial regulation is not the only area of regulation in which PBR is being debated. There are therefore risks in using it too heavily as an example of what PBR 'is'. In particular, there are certain peculiarities of the FSA regime which mean there are some issues of translation, as it were, to other regulatory regimes. Most relevant in this regard are the FSA's extensive enforcement powers and consequently the minimal role played by the courts in the enforcement process. ${ }^{20}$ This is a key difference in the institutional context between the UK and the US, where the courts are heavily engaged in the enforcement process both through public prosecutions and through class actions. ${ }^{21}$ The FSA enforcement regime is also distinct from many other regulatory regimes in the UK, where prosecution in magistrates' courts has until very recently often been the only route to the imposition of a formal sanction for breach of a regulatory rule, notably in health and safety and environmental regulation. Nonetheless, despite its institutional peculiarities, the FSA's pursuit of PBR is potentially relevant for other regulatory regimes, albeit with that important caveat in mind.

Even in the FSA context, however, in talking about the 'move' to PBR we should not get too carried away. The rhetoric of principles-based regulation may be beguiling, but principles based regulation does not necessarily mean the end of detailed rules. We are a long way from seeing blazing bonfires of rulebooks. Despite pruning back the rules on money laundering, training for wholesale firms and, to an extent, provisions on bundling and soft commissions, and the revisions

\footnotetext{
17 Blueprint, 11.

18 Bill 38, 5 ${ }^{\text {th }}$ Session, 37th Parl., Nos 72 and 73.

${ }^{19}$ For discussion see C. Ford, 'New Governance, Compliance and Principles-Based Securities Regulation' (2008) 45(1) Am Bus Law Jnl 1-60.

20 The Financial Services and Markets Tribunal, however, which is the appellate body with respect to the FSA's enforcement decisions, does play a significant role. How sympathetic it will be to the FSA's shift in approach remains to be seen, but early indications suggest it may demand a significant degree of precision from the FSA in its communications with firms as to what conduct is required in particular circumstances, even in the absence of detailed provisions: see Fox v Hayes FSMT Case 047 September 2007.

${ }^{21}$ For detailed comparison of the two enforcement regimes see H.E. Jackson, 'Variation in the Intensity of Financial Regulation: Preliminary Evidence and Potential Implications' (John M. Olin Center for Law Economics, and Business Discussion Paper No. 521) (August, 2005) available at http://ssrn.com/abstract=839250; J. Coffee, 'Law and the Market: The Impact of Enforcement', Centre for Law and Economic Studies, Columbia University Working Paper No. 304, available at http:/ / papers.ssrn.com/paper.taf?abstract_id=967482.
} 
made in the new Conduct of Business rules, ${ }^{22}$ the FSA Handbook still runs to several thousand pages. Moreover the extent to which it can dispense with many of its rules is increasingly constrained by EU law, where the idea of 'principles based regulation' has still to take hold, despite Commissioner McCreevey's rhetoric. Nor should detailed rules be banished from principles-based regulatory regimes. There are strong arguments for saying that a tiered approach to rule design should be adopted. Principles need an under-pinning of detailed rules in some areas, and detailed rules in turn need the support and coverage of principles to thwart strategies which seek to exploit gaps and inconsistencies in those detailed provisions. ${ }^{23}$ However, the shift in the FSA's approach to regulating which is occurring under the banner of PBR, particularly with respect to those firms engaged in the retail markets, is striking and marks a shift in approach which is as important as the FSA's move to risk-based regulation, two or three years earlier. ${ }^{24}$ Indeed, before turning to the different forms of PBR and the seven paradoxes, it is worth asking first why PBR has moved onto centre stage recently: in short, why have PBR?

\section{WHY HAVE PRINCIPLES-BASED REGULATION?}

Regulation has been described as 'low politics' - the world of mundane technicalities far below the 'high' politics of international diplomacy or national party politics. ${ }^{25}$ Yet regulation has recently taken political centre stage, not least as the credit crunch has exposed the contradictory demands of regulated firms and others for both less and more regulation, and the limits of governmental capacity to provide either, or at least not in the right places and in the right ways.

So why is there currently such prominent political attention being paid to the design and operation of regulatory regimes in general, and a favouring of PBR in particular? As noted above, the recent events in the financial markets have made the issue of PBR rather peripheral to the immediate concerns of rescuing the financial system from collapse. But prior to the deepening of the financial crisis, and in other regulatory domains, the political attraction of principles-based regulation, it is suggested, lies in its rhetorical invocation of a Utopian world. In this regulatory Utopia, regulation is targeted and focused, and preferably harmonized across jurisdictions, regulated firms are given the flexibility they need to get on with running their businesses, and consequently regulatory outcomes are achieved with no undue cost to business. It is a world in which regulators have

${ }^{22}$ For details see FSA, PBR.

${ }^{23}$ See J. Black, Rules and Regulators (Oxford: Oxford University Press 1997); id, 'Using Rules Effectively' in C. McCrudden (ed), Regulation and De-Regulation (Oxford: Oxford University Press, 1999) 95-121; J. Braithwaite, 'A Theory of Legal Certainty' (2002) 27 Australian Journal of Legal Philosophy 38.

${ }^{24}$ On which see J. Black, 'The Emergence of Risk Based Regulation and the New Public Risk Management in the UK' [2005] Public Law 512.

${ }^{25}$ M. Moran, The British Regulatory State, (Oxford: Oxford University Press, 2003) 33. 
sufficient perspective on and understanding of the problems and issues that they confront to be selective and to identify the key issues on which regulation should focus, in which there is sufficient agreement on principles and purposes to be able to agree with firms a common framework, and in which regulated firms are given the flexibility and responsibility to develop their own systems for ensuring that the regulatory principles are adhered to, but in a way which means their businesses can operate efficiently and innovatively in a stable regulatory environment.

The rhetoric of PBR thus invokes, not deregulation, but a re-framing of the regulatory relationship from one of directing and controlling to one based on responsibility, mutuality and trust. Regulators and regulatees move from a directing relationship of telling and doing, to a relationship in which regulators communicate their goals and expectations clearly in principles and apply those principles predictably, regulatees adopt a self-reflective approach to the development of processes and practices to ensure that these goals are substantively met, and, critically, both trust each other to fulfil their side of this new regulatory bargain.

The rhetorical invocation of such a world under the moniker of PBR is beguiling not only to policy makers and business, but to academics as well. The world invoked by the rhetoric of PBR is one which accords with the strategies of the 'new governance'26 or 'decentred regulation'. ${ }^{27}$ The decentred, or polycentric, analysis of regulation has three dimensions: organisational, conceptual and strategic. ${ }^{28}$ Organisationally, it draws attention away from individual regulatory bodies, be they at the national or global level, and emphasises instead the multitude of actors which constitute a regulatory regime in a particular domain. Conceptually, the decentring analysis has a particular understanding both of the nature of the regulatory problem and the nature of state-society and intra-state and intra-society relationships. It emphasizes the existence and complexity of interactions and interdependencies between social actors, and between social actors and government in the process of regulation. It has a dialectical conception of the regulatory relationships, in which regulator and regulatee are at once autonomous of and dependent on each other. It is also rejects the distinction between public and private: both state and non-state actors engage in the function of regulation, both separately and in different types of interrelationship, and indeed state actors may be regulated by non-state actors. ${ }^{29}$ The third dimension is

\footnotetext{
26 See n 19 above.

${ }^{27} \mathrm{~J}$. Black, 'Decentring Regulation: Understanding the Role of Regulation and Self Regulation in a "PostRegulatory” World' (2001) 54 Current Legal Problems 103; id., 'Critical Reflections on Regulation' (2002) 27 Australian Journal of Legal Philosophy 1.

28 J. Black, 'Constructing and Constesting Legitimacy and Accountability in Polycentric Regulatory Regimes' (2008) 2 Regulation and Governance 1.

${ }^{29}$ E. Meidinger, 'Look Who's Making the Rules: International Environmental Standard Setting by NonState Organisations' (1997) 4 Human Ecology Review 52-54; B. Cashore, 'Legitimacy and the Privatization of Environmental Governance: How Non-State Market Driven (NSDM) Governance Systems Gain Rule Making Authority' (2002) 15(4) Governance 503; M.E. Keck and K. Sikkink, Activists Beyond Borders: Advocacy Networks in International Politics (Ithaca, NY: Cornell University Press, 1998); T. Risse-Kappen (ed), NonState Actors, Domestic Structures and International Institutions (Cambridge: Cambridge University Press, 1995);
} 
strategic or functional. The hallmarks of the regulatory strategies which are engaged in decentred regulation are that they are hybrid: combining governmental and non-governmental actors; multi-faceted: using a number of different strategies simultaneously or sequentially), and indirect: co-ordinating, steering, influencing and balancing interactions between actors and creating new patterns of interaction which enable social actors to organise themselves. Decentred regulation thus engages the strategies of 'smart regulation' or 'new governance' which have been described in a wide range of writings on regulation, ${ }^{30}$ though does not see these as the sole preserve of the state.

Principles-based regulation fits well with the 'smart' regulatory strategies or those of 'new governance' associated with the decentred analysis. ${ }^{31}$ Principles provide the framework in which firms can organize their own processes to achieve the outcomes the regulator seeks; the regulator in turn depends on firms to adopt an attitude to the regulatory regime which is one which aims to go beyond minimal compliance with the rules. PBR thus both relies on and reinforces the image of the self-observing, responsible organization which is a central feature of governance strategies. ${ }^{32}$ Regulatory conversations as to the meaning and application of the rules take centre stage as their meaning and application is elaborated on in iterated communications between regulator and regulated. ${ }^{33}$ Rigid divisions of responsibility for producing rules between public and private actors are eschewed as third parties to the regulator-regulatee relationship, such as trade associations, are brought in to develop interpretations and guidance on their meaning. The strategy links with another key 'new governance' strategy, that of 'meta-regulation' or management based regulation, in which regulators focus not on detailed compliance but on whether the firm's internal systems and processes can deliver the outcomes which the regulator seeks. ${ }^{34}$ Principles impose outcomes to be achieved, not detailed processes for achieving them, thus allowing room for local or 'bottom up' elaboration and customization. They can thus help to overcome the problems of scale which all regulatory systems face: the move from

C. Scott, 'Private Regulation of the Public Sector: A Neglected Facet of Contemporary Governance' (2002) 29 Jnl of Law and Society 56.

30 See for example G. Teubner, 'Substantive and Reflexive Elements in Modern Law' (1983) 17 Law \& Soc Rev 239; id., 'Juridification - Concepts, Aspects, Limits, Solutions' in G. Teubner (ed), Juridification of the Social Spheres (Berlin: Walter de Gruyter, 1987); N. Gunningham and P. Grabosky, Smart Regulation: Designing Environmental Policy (Oxford: Clarendon Press, 1998), 38-50; J. Braithwaite, 'The New Regulatory State and the Transformation of Criminology' (2000) 40 British Jnl of Criminology 222; C. Parker, 'Reinventing Regulation within the Corporation: Compliance Oriented Regulatory Innovation' (2000) 35(2) Administration \& Society 529); D. O'Rourke, 'Outsourcing Regulation: Analyzing Non-Governmental Systems of Labor Standards Monitoring' (2003) 31 Policy Studies Journal 1; J. Freeman, 'The Private Role in Public Governance' (2000) 75(3) New York University Law Review 543.

${ }^{31}$ See also $n 19$ above.

32 See e.g. C. Parker, The Open Corporation (Cambridge: Cambridge University Press, 2002), chapter 9; M. Power, Organized Uncertainty: Designing a World of Risk. Management (Oxford: Oxford University Press, 2007) $41-42$.

${ }^{33}$ See further J. Black, 'Talking about Regulation' [1998] Public Law 77.

34 Parker, n 32 above; C. Coglianese and D. Lazer, 'Management Based Regulation: Prescribing Private Management to Achieve Public Goals' (2003) 37(4) Law and Society Review 691. 
the aggregate and the general, which is the level at which rules and principles operate, ${ }^{35}$ to the local and the particular, which is the site of their application. ${ }^{36}$

In invoking this regulatory Utopia, PBR portrays a world, if not of harmony, then of trust, responsibility and mutuality in which conflicts of interests and contests of power are glossed over, if not completely omitted from view. This is a powerful vision with obvious political appeal for politicians, regulators and firms alike. In the less Utopian vision, of course, the argument is that PBR is simply a licence for backsliding; for allowing regulatees to do what they want with regulators' pandering not kept in check by detailed rules which they have to enforce.

The FSA itself puts forward cogent reasons for adopting PBR which accord with the advantages of principles often noted in academic commentaries. It offers four main reasons for adopting a more principles based approach. Firstly, effectiveness: detailed rules, it argues, have been incapable of preventing misconduct in a range of areas, such as misselling of retail financial products. Secondly, durability: regulation that a focus on outcomes is more able to adapt to a rapidly changing market environment than one which is based on prescriptive rules. Thirdly, accessibility: principles are far more accessible to senior management and smaller firms in particular others than a bewildering mass of detailed requirements. Fourthly: fostering substantive compliance: a large volume of detailed provisions can divert attention towards adhering to the letter rather than the spirit of the rules, making it less likely that the FSA will achieve its regulatory objectives. ${ }^{37}$

The FSA itself may genuinely hold these reasons, but elsewhere, beyond the official rhetoric, there is also a clear sub-text to much of the political debate. In the US-UK context, and to an extent in the EU-UK contest, PBR is intimately embroiled in a competition between regulators (and their governments) for business. There is no doubt that, at least at the rhetorical level, PBR is a weapon in the fierce battle for business between London and New York. ${ }^{38}$ Against the plaudits of the McKinsey report and the US Treasury for the FSA's approach should be set Roel Campos's criticisms that the London Stock Exchange's regulation of its junior market, AIM, was too lax and that AIM was like a 'casino'. ${ }^{39}$ Although he subsequently argued his words had been taken out of

\footnotetext{
35 As do policy makers.

$36 \mathrm{~J}$. Black, Rules and Regulators, n 23 above, chapter 1.

${ }^{37}$ FSA, PBR, p.6.

38 The rhetorical battle has led Cunningham to argue that the debate should be abandoned and refocused on fundamentals: L. Cunningham, 'A Prescription to Retire the Rhetoric of 'Principles Based Systems' in Corporate Law, Securities Law and Accounting', Boston College Law School Research Paper no. 127, available at http://ssrn.com/abstract $=970646$.

39 Roel Campos, a member of the Securities and Exchange Commission, was quoted on a Dow Jones newswire in March 2007 as deploring the trend whereby companies simply chose their listing venue based on the lowest level of oversight available. Referring to AIM, he said: 'I'm concerned that 30 per cent of issuers that list on AIM are gone in a year. That feels like a casino to me, and I believe investors will treat it as such'. Mr Campos subsequently said that his remarks had been taken out of context and that he did not regard AIM as a casino. 'What I was referring to', he said, 'was a generalised situation in which if
} 
context, the barb clearly stung the Exchange, which offered a swift repost that Campos had misunderstood its principles-based approach. ${ }^{40}$ The deployment of PBR to fight political battles is not confined to securities regulation. In the context of accounting regulation, Kershaw has argued that in the wake of Enron's collapse, it was in part the ability of the UK accounting regulators to portray their approach as 'principles-based' which saved them from the political fallout which hit accounting regulation in the US. This was despite the fact that the relevant accounting provisions themselves in the UK and the US were almost identical. ${ }^{41}$

Using PBR as a weapon in a wider battle for institutional position is not new. An often forgotten fact is that the FSA's eleven Principles for Business, now taken as one of the hallmarks of a PBR regime, were themselves rooted in the ten Principles created by its predecessor (the Securities and Investments Board). These ten Principles were developed by SIB to mark out its institutional turf in a power battle with the self-regulatory organizations (SROs) in the pre-FSA regulatory regime. ${ }^{42}$ When the initial regulatory regime was created under the 1986 Financial Services Act, the Act was deliberately vague as to which should be the dominant regulator, the Securities and Investments Board (named in the Act and in receipt of powers to recognize self regulatory organizations) or the SROs themselves. SIB could recognize SROs but had no powers to direct them. Both organizations were responsible for directly regulating firms themselves, and the SRO's rulebooks had to provide 'equivalent' levels of protection to those provided by SIB's rules. However the SIB could not require SROs to amend their rules post-authorisation; the only sanction was the nuclear option of derecognition. After lengthy battles as to the relative power, authority and roles of SIB and the SROs, the Government agreed to amend the legislation to permit SIB to issue principles which were applicable to all authorized firms, and so which had to be recognized by the SROs. In addition, SIB was given powers to designate a number of its own rules as 'core rules', SIB rules which the SROs were required to incorporate into their own rulebooks. ${ }^{43}$ The ten Principles which SIB issued in 1992 were thus created only in part to achieve all the benefits of the Utopian vision; their primary motivation was to resolve SIB's institutional position and power with respect to the SROs.

So the Utopian vision can be a mask for a more gritty power battle. Yet, however unrealistic it may be for some, the Utopian vision is still attractive and strongly held by many. However its realization is by no means simple. This is in

(regulatory) standards are ignored and you have a spiral downward you could get into a situation where an exchange could be nothing more than a casino' (Financial Times, March 8, 2007).

40 The LSE has long sought to explain that principles do not equate to soft regulation: see eg D. Cruickshank, Chairman of the London Stock Exchange, 'The Same but Different: Hard Rules or Soft Principles - Perspectives on the US and EU Capital Markets', available at http://www.londonstockexchange.com/en-gb/about/Newsroom/Media+Resources/Speeches/ speech18.htm.

${ }_{41}$ R.D. Kershaw, 'Evading Enron: Taking Principles Too Seriously in Accounting Regulation’ (2005) 68 Modern Law Review 594.

42 Black, Rules and Regulators, n 23 above; id., 'Talking About Regulation', n 33 above, 77.

43 SIB designated 40 core rules; for discussion see Black, Rules and Regulators, n 23 above, ch 3. 
part for the normal, pragmatic reasons relating to the imperfections of human and organisational behaviour, the dangers of bureaucratic sclerosis in both firms and regulators, the tendency for regulators to, as Schauer puts it, 'round off' the hard corners of rules and 'sharpen' the soft edges of principles, ${ }^{44}$ and the fickle nature of political sentiment. Particularly in times of crisis, the pendulum of political support can swing away from principles and in favour of detail and prescription, as the current tone of the debate on financial regulation post-Northern Rock illustrates. However its realization is also problematic because of its paradoxical nature, explored further below.

\section{THREE FORMS OF PBR}

The political dimension to the debate obscures the different forms that PBR can take. The FSA's version of PBR contains three elements: a particular type of rule; a focus on outcomes; and a focus on senior management responsibility in ensuring these outcomes are achieved. ${ }^{45}$ That is only one form of PBR, however. In order for us to be clear as to what we are talking about, we need to distinguish different forms of PBR. First, formal $\boldsymbol{P B R}$ - it is possible, analytically and in practice, for a regulatory regime to have principles as part of its written norms, but for other aspects of the FSA's version, for example, to be absent. Secondly, there is substantive PBR. In substantive PBR, the principles present in the rule books are put into practice in one or more particular ways. It is important to note that these practices may also operate in the absence of principles being present in the rule books, for example through the flexible implementation and enforcement of a highly detailed set of rules. In other words, it can be delivered in a regime of detailed rules but in which regulators do not 'go by the book', in Bardach and Kagan's memorable phrase. ${ }^{46}$ Where both exist then there is full PBR. Finally, PBR can also be characterized by the engagement of a range of actors other than the regulator or regulated firm to develop interpretations of the principles: networked or polycentric PBR. This could be, for example, through the development of guidance or codes of practice, which could be approved by the regulator (as in the FSA's system of confirmed guidance) or not; or through interactions with consultants and others who assist firms in developing systems to ensure compliance.

\footnotetext{
${ }^{44}$ F. Schauer, 'The Tyranny of Choice and the Rulification of Standards', (2005) 14 Jnl Contemp. Legal Issues 803 .

$45 \mathrm{n} 14$ above; FSA, PBR.

46 E. Bardach and R. Kagan, Going By the Book: The Problem of Regulatory Unreasonableness (Philadelphia, Temple University Press, 1982).
} 


\section{FORMAL PBR}

At the formal level, principles-based regulation means the presence of general, broadly stated rules, or 'principles', to set the standards by which regulated firms must conduct business. ${ }^{47}$ The term 'principles' can be used simply to refer to general rules, or also to suggest that these rules are higher in the implicit or explicit hierarchy of norms than more detailed rules: they express the fundamental obligations that all should observe. Principles are used in both these senses in the FSA context. The eleven Principles for Business are general rules, which set out the main obligations on firms, and are the provisions from which the other rules and guidance in the FSA Handbook flow. ${ }^{48}$

The use of broadly stated standards, rather than reliance solely on more detailed and prescriptive rules, has been a feature of the regulatory regime for financial services since 1992. The FSA's Principles for Business have a number of characteristics: 49

- they are drafted at a high level of generality,

- they contain terms which are qualitative not quantitative

- they are purposive, expressing the reason behind the rule.

- they are mainly behavioural standards, focusing on, for example, the "integrity", "skill care and diligence" and "reasonable care" with which authorised firms or approved persons conduct and organise their businesses and the fairness with which they treat customers and manage conflicts of interest.

Similar examples of rule design can be seen in the Combined Code on Corporate Governance, the BCSC's Bill 38; the 'true and fair view' principle in accounting; in the Listing Rules and in the London Stock Exchange's rules for those admitted to its junior market, the Alternative Investment Market (AIM) and their nominated advisors (Nomads). 50

It is however sometimes argued that there is no real difference between principles and rules. ${ }^{51}$ In strictly legal terms this is true; and indeed some rules in the FSA Handbook are as general as some of the Principles for Business, for example the provision on suitability. But principles are not necessarily distinguished from other types of rules on the basis of their legal status. Cunningham also argues that even if rules can be distinguished from principles

\footnotetext{
${ }^{47}$ There is a vast literature on the distinction between rules and standards or principles - for review see $\mathrm{J}$. Black, Rules and Regulators, $\mathrm{n} 23$ above.

${ }^{48}$ It is worth noting that there are other broadly based rules in the FSA handbook which have the same structure as principles, but have the status of rules, for example the provisions on suitability.

${ }^{49} \mathrm{n} 14$ above.

50 On which see further below.

51 L. Cunningham, A Prescription to Retire the Rhetoric of "Principles-Based Systems" in Corporate Law, Securities Regulation and Accounting (Mar. 13, 2007), (Boston College Law School Research Paper No. 127), available at http://ssm.com/abstract $=970646$.
} 
this tells us little about the character of the regulatory regime. This is also true, and it is the reason for suggesting the distinction between different types of PBR. As the characterization presented here of 'formal' PBR indicates, the mere presence of principles does not mean that the modes of implementation and enforcement will take any particular form. ${ }^{52}$ Further, it is also the case that the rules versus principles debate, particularly as played out in the context of judicial interpretation, is a less a debate about the technical form and linguistic structure of written norms and more a political debate on the role of the judiciary. ${ }^{53}$ In the regulatory context the debate on interpretation of principles and their 'uncertainty' is also often at base a political debate on the proper role of the regulator.

With these caveats in mind, it is nonetheless worth stepping back and analyzing the different dimensions of rules to clarify just what distinguishes a principle from a detailed rule: in other words what characterizes PBR at the formal level. A rule, any rule - legal or non-legal, issued by a regulator or formed within a firm - has a number of different dimensions. ${ }^{54}$ These are first its substance: what it concerns. Second, its status: whether it is legally binding or not, and the sanction, if any, which attaches to its breach. Third, its character, whether it prohibits, permits, discourages or mandates certain behaviour. Fourth, its linguistic structure: whether the language which the rule uses is vague or precise, whether the rule is simple or complex in its requirements, whether its language is clear and easily understood, or opaque.

These dimensions constitute decision points for anyone writing a rule or principle: what legal status should the rule have: binding, evidential, guidance only, or a safe harbour (status); should it seek to encourage behaviour or mandate it (character); should there be any consequences flowing from its breach, if so of what sort (sanction); should the rule use terms which are vague in that they are evaluative ("suitable", "reasonable") or lack specification as to the manner in which an action is to be performed ("inform" or "publish", act "promptly"), or should compliance with it require the existence of a complex set of facts or criteria, or should the rule be a simple and precise "bright line" rule, like a speed limit (eg notification to the regulator to be made 'within one working day') (structure).

Any combination of the different dimensions is possible, whatever the institutional context in which the rule is being formed (with the obvious exception that only certain rules will be recognised by the courts as having legal status). ${ }^{55}$ It is

\footnotetext{
52 So dealing with Cunningham's opposition to the use of the term 'PBR': Cunningham, ibid.

53 D. Kennedy, 'Form and Substance in Private Law Adjudication' (1976) 89 Harvard LR 1685.

54 Dimensional analyses are fairly common in the literature on the use of rules in regulation, although they vary slightly. That set out here is developed more fully in Black, Rules and Regulators, n 23 above, chapter 1; see also R. Baldwin, Rules and Government (Oxford: Clarendon Press, 1995); C.S. Diver, 'Regulatory Precision', in K. Hawkins and J.M. Thomas (eds), Making Regulatory Policy (Pittsburgh: University of Pittsburgh Press, 1989); C.S. Diver, 'The Optimal Precision of Administrative Rules' (1983) 93 Yale LJ 65.

55 The analysis proposed is one of rules, and thus is relevant wherever rules (defined as norms governing behaviour) are used, be that internally within organisations, as systems of private ordering in self regulatory or other 'soft law' regulatory regimes either nationally or globally, or as public or statutory systems of regulation. The particular context of rule use which is being examined here, however, is that of a national system of regulation, and so the discussion of examples and implications will operate within that context.
} 
the dimension of structure which is relevant in characterising a norm as a principle. A rule's structure has three elements: precision, complexity; and clarity. Each of these elements is a spectrum: at one end the rule may be extremely precise (30 days), at the other end it may be very general (in a reasonable time). It may range from being very simple (no entry) or highly complex (no admission for the following under the following circumstances). Varying the choices as to these elements of structure produces rules of three broad types: bright line rules, principles or detailed and complex rules. Table 1 illustrates how these different types could be used hypothetically (and in approximate terms) to communicate the requirements with respect to timely execution. ${ }^{56}$

Table 1: Rule types illustrated

\begin{tabular}{|l|l|l|}
\hline \multicolumn{1}{|r|}{ Type 1: Bright line } & \multicolumn{1}{|c|}{ Type 2: Principle } & \multicolumn{1}{|c|}{$\begin{array}{l}\text { Type 3: Complex / } \\
\text { detailed rule }\end{array}$} \\
\hline $\begin{array}{l}\text { A firm must execute } \\
\text { all orders of under } \\
10,000 \text { securities within } \\
\text { one business day. }\end{array}$ & $\begin{array}{l}\text { A firm must pay } \\
\text { due regard to the } \\
\text { interests of its customers } \\
\text { and treat them fairly. }\end{array}$ & $\begin{array}{l}\text { A firm must execute } \\
\text { all orders for customers } \\
\text { within one business day in } \\
\text { the following } \\
\text { circumstances [definition } \\
\text { of customer; definition of } \\
\text { order; restriction as to } \\
\text { whether discretionary } \\
\text { dealing or execution only; } \\
\text { circumstances where } \\
\text { orders may be worked } \\
\text { over a longer period etc] }\end{array}$ \\
\end{tabular}

The Type 1 rule is a "bright line" rule: it sets out a single criterion which has to be satisfied for the rule to apply, expressed as a quantitative measure. It is clear and straightforward to apply, but as is well recognised, can fail to achieve its purpose (fair treatment of customers) as there may be circumstances in which customers' interests would be better served by executing orders of under 10,000 securities over a longer period. It is easy to manipulate or "creatively comply" with (orders could be aggregated to avoid the rule) and indeed the rule may be missing the point completely as volume amount is not necessarily a good measure on which to identify which customers are in need of this requirement of firms.

The Type 2 rule, the "Principle", is quite different in nature. It expresses the aim of the rule and speaks to those who are in practice exercising control within the firm. It is focused on the substantive objective. However, whether or not it is certain depends on whether both regulated firms and the regulator agree on what constitutes "paying due regard" and "treating customers fairly". Moreover, whilst

56 Taken from n 14 above. 
it looks simple to apply (there is just one condition to meet), in practice a whole range of factors will have to be considered, which may make it as complex to apply as a Type 3 rule.

Type 3 is a detailed or complex rule. The list of conditions that have to be met for the rule to apply or be complied with can mean it has a higher congruence than a Type 1, bright line rule, but only if they are the appropriate criteria. It can thus potentially have the congruence of a Principle but provide more certainty than a Principle as it elaborates on what the conditions/factors are that have to be taken into account. That elaboration makes it complex to apply, however (more information is necessary, more factors have to be taken into account), and the creation of a list inevitably will leave gaps and again give scope for manipulation or creative compliance.

Principles thus have the benefit of congruence: of communicating the regulatory objectives and promoting behaviour which will achieve those objectives. Moreover, as far as regulators are concerned, they have the benefit of minimising the scope for "creative compliance". Whether they are simple to apply depends on the number and type of factors to be considered in assessing their application.

But the third, most contested element of principles, the degree to which principles are clear or opaque and thus whether their application is certain or uncertain, cannot be read off the face of the rule. Rather that depends on the extent to which the rule is clear in practice to those who are reading it. Contrary to lawyers' dearly held beliefs, there is no necessary correlation between precision and certainty, or at least not after a certain point. The more precise the rules, the more complex they become, the greater the number of 'gaps' that are created, the greater the potential for internal inconsistencies in their application, the more uncertain their application becomes in any particular circumstance. Certainty does not come from the structure of the rule or principle per se, but from the interpretation it receives. Whether a rule, principle, or any written norm is certain depends on the extent to which there is a shared understanding as to their meaning and application within and between regulator, regulated and any organization (regulatory decisions committee, court or tribunal) called upon to make a determination. ${ }^{57}$ Developing that shared understanding can be facilitated by using fairly precise rules, but once rules become overly precise and complex then it can be significantly hindered.

The presence of such fundamental tradeoffs means that the optimal use of rules is to have rules of each different type, and to aim for achieving the benefits of compensatory effects between them. In other words, to have a tiered rule structure, with principles supported in particular instances by detailed rules. ${ }^{58}$ However, simply in terms of defining PBR at the formal level, we can say that a regulatory regime is principle-based at the level of form if it contains norms which use simple,

57 Black, 'Talking about Regulation', n 33 above.

58 Black, 'Using Rules Effectively', n 23 above; Braithwaite, 'A Theory of Legal Certainty', n 23 above. 
general terms and which express the reason for the rule, and if the norms are seen as expressing the fundamental obligations that all subject to them should observe.

\section{SUBSTANTIVE PBR}

As noted above, however, there can be more to PBR than just the presence of principles. The regulatory Utopia invoked by PBR is not one of a perfectly designed rulebook, but of a regulatory regime based on mutuality, trust and responsibility. The debate is not on issues of legal form for their own sake, but on the type of behaviour of both regulator and regulated firms that it is hoped that the use of principles will elicit. Contrary to the implicit assumptions behind much of the rhetoric of PBR, however, this behaviour does not automatically follow from the presence of principles. Kershaw's analysis of the relevant accounting provisions applying to Enron shows that both the US and the comparable UK requirements contained almost identical principles and rules. ${ }^{59}$ What distinguishes the two systems is, amongst other things, not so much what their rules looked like, but how they are applied. It is this difference in implementation and application which marks out the substantive difference between the US and the UK regimes which politicians are increasingly commenting on.

This is not to say that legal form is irrelevant. Principles are necessary for full PBR (formal plus substantive PBR) to exist. However, it is to argue that a regime can still have the substantive character associated with PBR without having principles. So what are the main elements of substantive PBR? Both the debates that are occurring and the approaches being used by regulators who are held up as 'doing' PBR suggest that there are five sets of regulatory practices, the presence of all or any of which can characterize substantive PBR. These are a particular mode of interpretation, a particular enforcement style, an orientation to outcomes, a reallocation of responsibilities for working out the practical application of the provisions, and an explicit and developed reliance on management based regulation.

The first characteristic is the approach taken to interpretation. In substantive PBR, the application of principles is characterized by three things. First, a dense network of 'regulatory conversations': dialogic, iterative and reflexive communications between regulator, regulatee and others as to the purpose and application of the principle. In other words, a series of repeated and reasoned interchanges, conversations, between regulator and regulated as to the meaning and application of the principles in particular circumstances. Secondly, responsibility for developing interpretations and applications is shared between regulator and regulatee, though each have somewhat different roles. Firms have to take responsibility for thinking through the application of the principle to specific circumstances; regulators have the responsibility to give clear guidance. Thirdly disputes over their application are resolved through purposive

${ }^{59}$ n 41 above. 
interpretations and consequentialist reasoning. The mode of interpretation adopted in substantive PBR, at least in the regulatory context, is thus at odds with the formal canons of traditional contractual interpretation, at least at common law, where interpretation has historically been formal, literal and nonconsequentialist. ${ }^{60}$ As will be suggested below, this difference in interpretive approach is probably one of the main reasons lawyers resist PBR, at least as practised by regulators, but probably one of the main reasons politicians, regulators and senior managers are attracted to it. ${ }^{61}$

The second element of substantive PBR is enforcement. The nature of the enforcement regime is a critical element of PBR. Under PBR, firms are required to think through the application of the provisions to particular situations to a far greater degree than they are with respect to a detailed rule. There is thus a greater risk that they will make the wrong assessment, ie one with which the regulator does not agree. We can call this interpretive risk. They will seek to minimize this risk by calling for greater prescription from the regulator. In the absence of that prescription, the enforcement approach is critical. In a regime with a tough, punitive approach in which every infraction is met with a sanction, PBR will not survive. It will transform into a system of detailed requirements, as that is what firms will need. They will demand rules to provide them, and the regulator, with clear boundaries.

Here the political aspects of the debate become relevant. Enforcement is a key part of the story being told as to the relative strengths and weaknesses of the US and UK regulatory regimes, at least in the context of securities regulation. Howell Jackson's work on the resources spent on enforcement in the US and the UK show a striking disparity between the two countries, with the US spending significantly more than the UK, allowing for the relative size of their markets. ${ }^{62}$ These figures have in turn been used by Coffee to suggest that high levels of formal enforcement action produce an optimal level of regulation with respect to certain types of firms, measured by cost of equity capital. 63

The debate taps into a long standing debate in the regulatory literature between the 'deterrence' and 'compliance' models of enforcement: do you go hard after every infraction, or adopt a more negotiating stance. For those in favour of negotiative approaches, formal enforcement action provides clear evidence of enforcement styles, but it does not on its own provide evidence of compliance. Instead it can promote increased non-compliance as it raises the regulated firms' hostility to the regulatory regime as a whole. For those in favour of deterrence based approaches, only tough, formal enforcement actions will ensure that calculating firms obey the rules; negotiated approaches lead to non-compliance

\footnotetext{
60 Albeit with exceptions. See eg ICS v West Bromwich [1998] All ER 97 (interpretation can be purposive where evident mistake). I am grateful to Joanna Benjamin for this point.

61 On the support given by senior management see Norton Rose, Insuring the Future (London, 2007).

62 Jackson, n 21 above.

63 J.C. Coffee, 'Law and the Market: The Impact of Enforcement' Working Paper no 304, April 2007, available at http://papers.ssrn.com/paper.taf?abstract_id=967482.
} 
persisting and offenders going unpunished. The conventional wisdom is that neither extreme is an effective approach to take; instead regulators should do both: first negotiate, then if the firm still does not deliver substantive compliance regulators should gradually move up the enforcement pyramid, applying sanctions of increasing severity until they do. ${ }^{64}$

This 'responsive' enforcement approach is not contingent on any particular rule design, however. It can operate in systems of highly detailed rules, or where the rules are mainly principles, or where there is a combination of the two. That said, different rule types make it easier for regulatory officials to deal with certain types of regulated firm, as Baldwin has pointed out. Those who know what they are meant to be doing and are generally inclined to do it (the well intentioned and well informed) are best dealt with using a negotiating strategy, which is easier to do using principles. In contrast, those who do not know what they are meant to be doing and even if they did would not be inclined to do it (the ill intentioned and ill informed) are best dealt with using a strategy that escalates quickly up the enforcement pyramid, for which bright line rules are more effective. A supervisor can simply tell them: just do this because that is what the rule says. ${ }^{65}$

The point here is not what rule type is most effective for which type of regulated firm, though that is relevant, but the enforcement approach used. Substantive PBR requires a broadly 'responsive' mode of supervision and enforcement, in which negotiation as to the meaning, application and purpose of the rule plays a central role, and in which the focus is on the outcome that is to be achieved.66 However, whilst a 'responsive' approach to enforcement may be facilitated by rules of certain types, it is not contingent on them. So in the area of enforcement there can be, at least in this sense, substantive PBR without the form. The British Columbia Securities Commission provides a good example. As noted above, even though the BCSC has not been able to introduce principles, it has introduced the substantive aspect of PBR through changes to the manner in which it monitors and enforces its regulatory requirements. ${ }^{67}$

That is not to say that formal enforcement action is absent in PBR. Significantly, having initially said it would not use Principles alone as a basis for enforcement action, the FSA has recently shifted to doing just that. A number of high profile enforcement actions have been taken based on breach of a principle or principles alone. A good example is the action taken by the FSA against Citigroup with respect to a trading strategy adopted by five traders in its London office: the 'Dr Evil' trades. ${ }^{68}$ The traders developed an electronic trading

\footnotetext{
${ }^{64}$ I. Ayres and J. Braithwaite, Responsive Regulation (Oxford: Oxford University Press, 1992).

65 R. Baldwin, n 54 above.

66 What 'responsive' can consist of is elaborated in R. Baldwin and J. Black, 'Really Responsive Regulation' (2008) 71(1) Modern Law Review 59.

${ }^{67} \mathrm{n} 19$ above.

68 Breach of a Principle must involve an element of fault for a sanction to be imposed: FSA Handbook PRIN 1.1.7G where it states that 'Under each of the Principles the onus will be on the FSA to show that a firm has been at fault in some way.' . It should be emphasized that there is no right of private civil action against a firm for breach of a Principle: s.150 Financial Services and Markets Act 2000 (although it
} 
programme that would place sell orders simultaneously for a particular German government bond across a number of European markets. The strategy resulted in orders being sent for more bonds than existed, the closure of at least one market and the disruption of a number of markets for several days. They sold EUR12.9bn of European government bonds within seconds, and then bought back EUR3.8bn at lower prices, giving the bank a significant profit. The trades triggered several regulatory investigations and angered European governments. No rule was breached, but the FSA brought enforcement action on the basis of two Principles alone. It fined Citigroup $f 4 \mathrm{~m}$ and required it to disgorge its profits of $f .9 .96 \mathrm{~m}$ for breach of Principle 2, failing to conduct its business with due care and diligence, and Principle 3, failure to organise its affairs responsibly and effectively and to implement adequate risk management systems. ${ }^{69}$ The episode showed one of the key advantages, for regulators, of principles: it saved them from the limited foresight of rule makers. This particular trading strategy had never been envisaged by the rule makers, or indeed anyone else in the market, and so there was no particular rule against it. Yet clearly some form of regulatory action was appropriate. The Principles for Business provided the FSA with the means to take this action, which had the rule book consisted only of particularised rules it would not have been able to take.

A third characteristic of substantive PBR is a focus on outcomes. Again, there is no analytical correlation between using rules of a particular type (principles) and outcome based regulation. Targets are outcomes, and they can be extremely precisely defined, and as such as open to gaming and 'creative compliance' as detailed rules. Studies of how hospitals and other public service providers 'game' the performance targets set for them by central government illustrate this very clearly. ${ }^{70}$ However, in substantive PBR outcomes are defined in qualitative and / or behavioural terms: for example to act 'with integrity', 'fairly', 'in the best interests of the client'. ${ }^{1}$ It is hard to game purposive provisions of this nature.

It can also be difficult to understand what they mean in any one set of circumstances, however - the usual complaint that PBR is too uncertain. But there are various strategies that can be used to provide certainty and to build 'interpretive communities' as to the meaning and application of the rule. Developing guidance is the most obvious strategy, but the FSA's Treating Customers Fairly (TCF) initiative is an alternative example of how this meaning can be built. In contrast to both the supporters and detractors of PBR who consider it to be 'light touch' regulation, the FSA's TCF initiative, which it holds

should be noted that there are rules of a similar character in the Handbook to which the private right of action does attach, for example the rule on suitability). See $\mathrm{n} 14$ above for discussion.

${ }^{69}$ FSA, Final Notice to Citigroup Global Markets Limited, 28 th June 2005.

70 C. Hood, 'Gaming in Targetworld: The Targets Approach to Managing British Public Services' (2006) 66(4) Public Administration Review 515.

71 Outcomes are usually distinguished from outputs in performance evaluations: outputs are easier to game than outcomes. 
up as a key example of PBR, is a long way from being a hallmark of unintrusive regulation. The TCF initiative is underpinned by Principle 6 which requires firms to treat customers fairly. There are six TCF goals:

- Consumers can be confident that they are dealing with firms where the fair treatment of customers is central to the corporate culture

- Products and services marketed and sold in the retail market are designed to meet the needs of identified consumer groups and are targeted accordingly

- Consumers are provided with clear information and are kept appropriately informed before, during and after the point of sale

- Where consumers receive advice, the advice is suitable and takes account of their circumstances

- Consumers are provided with products that perform as firms have led them to expect, and the associated service is both of an acceptable standard and as they have been led to expect

- Consumers do not face unreasonable post-sale barriers imposed by firms to change product, switch provider, submit a claim or make a complaint.

The implementation of TCF has focused on providing firms with flexibility to devise their own systems for ensuring these goals are met. The FSA has published implementation reviews including case studies and examples of good and poor practices. ${ }^{72}$ But the intensity with which it has reviewed firms' internal operations is significant. The whole product cycle has been investigated from cradle to sale and then to post-sale. Firms are required to demonstrate that at each stage of product development, marketing and sale the interests of the customer are of central concern. TCF is still in the throes of implementation and we have yet to see whether it has an impact on reducing misselling, or what enforcement action will follow from failure to achieve the FSA's outcomes. However the point here is not its effectiveness, but its substantive nature: in this case the very close engagement of regulator and regulated firm in elaborating on the meaning and application of just one FSA Principle using a supervisory strategy which goes well beyond that of more familiar supervision and inspection regimes.

The fourth characteristic of substantive PBR is that the responsibility for ensuring that the objectives of the principles are met is shifted, in part, from the regulator to the regulated. More general rules (principles) allow firms greater discretion as to what to do. With that discretion comes the need, and responsibility, for working out what they should do. Where the balance should be struck between firms thinking for themselves and the regulators providing guidance is endlessly contested, and each thinks the other should be doing more. Firms want more specific guidance; regulators think firms should work it out.

72 These are published as 'cluster reports' and are available at http://www.fsa.gov.uk/Pages/Doing/ Regulated/tcf/ cluster/index.shtml. 
Firms do not want to do the regulators' job for them; regulators do not want to become unpaid consultants. This tension in their relationship, as to what the regulatory compact entails, is not unique to PBR regimes. Regulators implementing detailed rules face the same tension, as the National Audit Office's recent review of the five largest regulators in the UK illustrates. ${ }^{73}$ But PBR involves a significant shift in responsibility to firms, and requires a substantially different set of skills on the part of inspectors and compliance staff to engage in the negotiations and qualitative judgements that are entailed.

The final element which can characterise substantive PBR is a focus by the regulator on the firm's internal systems of management and controls - referred to in the regulatory literature as 'meta-regulation' or management based regulation. ${ }^{74}$ As with enforcement, meta-regulation can and does operate in systems where there are detailed rules. Given that any regulatory regime requires firms to internalize the regulatory requirements into their own systems and processes for it to be complied with, meta-regulation could be argued to be not so much a radical new strategy as regulators making a virtue out of a necessity, or at least recognizing that necessity. In management-based or meta-regulatory regimes, the regulator focuses its attention on ensuring that the firms' own internal rules, systems and processes are such that they will ensure compliance. As Power comments, internal management systems become the critical interface between regulatory and business values, and hence between society's and the organisation's goals and operations. ${ }^{75}$ Again the emphasis is on substance not form, under the substantive model. Regulators and firms should be focused on the outcomes those systems and processes deliver, not just on the form they take.

Meta-regulation has its limitations, not least that firms' own processes will be geared towards the firms' own ends, notably the production of profit, and not the regulators' ends, and the two do not always coincide. If they were the same, there would be no reason for firms to be regulated in the first place. Firms, and their legal advisors, may complain that they are being required to deliver on the regulator's wider social objectives, but that is the point of regulation, to ensure that firms do so deliver (at least under anything resembling a public interest model of regulation). However the gap between the systems required by the firm for its own purposes and those required by the regulator may be significant, not withstanding the perennial cry that compliance can be good for business, that reputation is critical and that firms lose their social licence to operate at their peril. ${ }^{76}$ Meta-regulation, like any regulatory strategy, has its limitations, but again

\footnotetext{
73 NAO, Regulatory Quality: How Regulators are Implementing the Hampton Vision (London, 2008), para. 4.5 notes that 'Regulators with direct inspection responsibilities face [the] challenge ... of determining where to draw the line between their preferred stance of neutral guidance provider and educator of business and the more hands on consultant-cum-management role many businesses seem to want.'

74 Parker, n 32 above, chapter 9.

75 Power, n 32 above, 42.

76 On social licence see N. Gunningham, R. Kagan and D. Thornton, 'Social License and Environmental Protection: Why Businesses Go Beyond Compliance" (2004) 29 Law and Social Inquiry 307.
} 
the point being made here not necessarily the effectiveness of meta-regulation, but its presence as an element of substantive PBR.

So in short, substantive PBR has five characteristics, all or any of which may be present in the operation of the regulatory regime. These are a purposive approach to interpretation worked out through iterated regulatory conversations; a broadly 'responsive' approach to enforcement; a focus on outcomes, a greater requirement on firms to think through the application of the principles, and the adoption of meta-regulatory techniques. With the possibly exception of the shift in responsibilities, none of these regulatory practices which can characterize substantive PBR needs to be accompanied by formal PBR; i.e. principles do not have to be present in the rulebooks for them to operate, as the example of BCSC demonstrates, ${ }^{77}$ though they can be facilitated by the presence of principles. On the other hand, formal PBR does not necessarily entail substantive PBR, as the example of the implementation of the US GAAP illustrates. ${ }^{78}$ Where the two are combined, as to an extent in the FSA context, we can talk of full PBR.

\section{POLYCENTRIC / NETWORKED PBR}

Finally, full PBR can be characterized by the interaction of a number of actors, not just regulator and regulated firm, who develop interpretations of the principles and their applications in particular circumstances. One example is the use of trade associations and others to produce guidance on the meaning and application of the principles. This is a strategy which the FSA has been using to an increasing degree. In the area of money laundering, it has reduced its rules to two pages, preferring to rely instead on the provisions of the Joint Money Laundering Steering Group. Reducing the amount of rules in the area of money laundering was worthwhile, but the equivalent of picking low hanging fruit - the rules as they were mainly reiterated the provisions of either the statutory instruments or the JMSLG's guidance. There are other examples where the FSA has actively facilitated the production of guidance by requiring representatives from different parts of the industry to agree on the contested issue of soft commissions. As part of its PBR initiative, the FSA has also introduced a system of 'confirmed' guidance, whereby it will 'confirm' industry guidance on the application of the principles. The status of such guidance, the FSA has stated, is that it will act as a 'shield' not a 'sword'. In other words, conduct in accordance with the guidance can be used as a 'shield' against enforcement action (though it does not have the formal status of a safe harbour), but non-conformity with the guidance will not be used as a 'sword' by the FSA with which to impale firms. ${ }^{79}$

However, there are other examples of polycentric PBR which rely on more than guidance; they include third parties as active interpreters, monitors and enforcers of rules. An example here is of the role played by NOMADs in the

\footnotetext{
77 n 19 above.

$78 \mathrm{n} 41$ above.

${ }^{79} \mathrm{FSA}, \mathrm{PBR}$.
} 
regulation of the London Stock Exchange's junior market, the Alternative Investment Market (AIM). ${ }^{80}$ Nomads, or 'nominated advisors', have to be appointed by any firm seeking admission to AIM, and significantly firms have to retain a Nomad during the course of their admission. The role of the Nomads is essentially to guide firms on the meaning and application of the AIM rules, which themselves often take the form of principles. Thus they are to ensure that firms have 'appropriate' systems of corporate governance, for example. Those who participate in AIM, their regulators and advisors all talk of the 'AIM community', and it provides a good example of an interpretive community. Through numerous interactions between Nomads, advisors, firms and regulators, understandings as to appropriate standards of conduct and courses of action have developed over time. And like other interpretive communities, it is vulnerable to the introduction of outsiders who upset this homogeneity of implicit understandings. The intrusion requires the production of 'clarifications' to render explicit some of those implicit understandings, as occurred in AIM's restatement of its rules in 2007. But the dense network of actors and interactions which supports PBR remains more or less intact.

Finally, consultants and voluntarily appointed advisors, including legal advisors, can play a key role in shaping the form that PBR takes within organizations. They can play a critical role in elaborating on the meaning of the principles and in developing those internal systems and controls on which regulation relies. This example of the potential polycentricity of PBR is not one which is designed or officially sanctioned by the regulator. It can be vital, however, and is a role which is explored further below.

\section{PARADOXES OF PBR}

Analysing the different forms of PBR is useful for clarifying the debate on PBR and providing some way through the rhetoric. However, in order to understand better the nature of PBR in its different forms, we need to move beyond the rather stale debate on its advantages and disadvantages, and recognize that PBR in its various forms contains certain paradoxes or self contradictory elements. The presence of these paradoxes does not necessarily suggest that PBR should not be attempted; there are still strong arguments for full, and indeed polycentric, PBR. However they illustrate the complexities involved in such an attempt, and thus exploring their nature can help move both the academic and policy debate on from both rhetorical flourishes and detailed lists of pros and cons. Here seven key paradoxes are identified and briefly outlined.

${ }^{80}$ For fuller discussion of the Nomad system see S. Arcot, J. Black and G. Owen, From Local to Global (London, 2007). 


\section{PARADOX 1: THE INTERPRETIVE PARADOX: PRINCIPLES CAN BE GENERAL YET PRECISE}

Principles, as explained above, are formally characterized by general, imprecise terms. This is meant to give flexibility. However, in practice principles can receive very specific interpretations. There can be benefits: certainty is produced through the development of an interpretive community which gives particular content and meaning to the principles. However, interpretive communities can fracture, and the regulatory regime may contain several interpretive communities, each with a different interpretation.

In particular, the interpretation which develops within the regulator may in practice be quite specific but not necessarily well understood. For example, the AIM rules do not specify the proportion of shares which should be made available on admission, but the LSE's rule of thumb is that at least $10 \%$ of the share capital has to be made available to the public. ${ }^{81}$ In AIM's case, the AIM community is aware of this interpretation, but where interpretive communities are not as strong, this may not be the case. The tendency for rules to become formalized in practice is well-observed, to the extent that a significant gap can grow between the written word and the bureaucratic interpretation it receives. Dan-Cohen talked of this in terms of the 'acoustic separation' of law. ${ }^{82}$ Specific interpretations may develop for reasons of bureaucratic ease (it saves supervisors having to think every time what conduct they should allow, enables consistent application), or because the regulator has taken a clear policy decision, not communicated in the rules themselves, that this is the interpretation that should be given. Whichever the reason, the operation of this interpretative paradox means that PBR exists only at the formal level, and in practice can be almost indistinguishable in places from a regime characterized by detailed rules. ${ }^{83}$

\section{PARADox 2: THE COMMUNiCATIVE PARADOX: PRINCIPLES CAN FACILITATE COMMUNICATION BUT CAN ALSO HINDER IT}

In using relatively straightforward language in expressing the purpose of the rule, PBR can facilitate communication. Indeed that is often one of the rationales for its introduction - to communicate better to regulated firms what their responsibilities are under the regulatory regime, as noted with respect to the FSA above. ${ }^{84}$ However, PBR can hinder communication in practice: a communicative paradox. In part, this can arise if there is a proliferation of guidance, and particularly if regulators are undisciplined in their provision of guidance. This lack

\footnotetext{
81 ibid.

82 M. Dan-Cohen, 'Decision Rules and Conduct Rules: On Acoustic Separation in Criminal Law' (1984) 97 Harvard L.R. 625.; see further Black, 'Talking about Regulation', n 33 above.

83 See eg Schauer, n 44 above; F. Schauer, The Convergence of Rules and Standards, (2003) 34 N.Z. L. Rev 303.

${ }^{84} \mathrm{FSA}, \mathrm{PBR}$.
} 
of discipline is a significant issue with the FSA's own development of PBR, where elaboration on the scope and implementation of TCF, for example, comes in a plethora of speeches, policy documents and miscellaneous communication documents. This verbal outpouring by the FSA makes it hard for regulated firms to know just what the FSA is requiring of them, raises fears that they have 'missed something' in this miscellany of communications, and in turn produces uncertainty and an atmosphere of concern and trepidation, as every speech by an FSA official is poured over by compliance officials and their legal advisors for the slightest hint of changes to the FSA's approach.

But there is a more fundamental source of the communicative paradox, which is that regulators and lawyers have a different interpretive schema, even though both are interpreting legal norms. The paradox arises because legal use of language is distinct from ordinary use of language, such that it requires training to understand it. 85 The extent of the difference is highlighed by formal linguistic analyses, which study the abstract rules that govern language use. ${ }^{86}$ Such analyses draw attention to the particular lexicality of law (its use of words which are unique to it), the greater instance of mononyms (using words with only one accepted meaning), a high incidence of 'restricted connotations'(the deprivation of words of their ordinary language connotations when transformed into legal discourse), and the particular syntactical structures of legal documents including statutes, all of which serve to distance 'legalese' from the ordinary language on which it otherwise draws. ${ }^{87}$ Law tries to cope with the problem of interpretation through what Goodrich terms the 'isolation of the code'. ${ }^{88}$ Control over the interpretation of legal instruments lies normally in the preserve of lawyers and ultimately the courts and occurs in accordance with strict rules of interpretation.

However regulatory practices, understandings and reasoning can be very different from those of the legal interpretive community, even though the rules in question have legal status. Enforcement actions are taken in part with a view to 'making an example' of someone as part of a strategic use of enforcement action. Regulatory enforcement decisions are messages to the wider regulatory community, they are not just concerned with the disposal of a dispute between two parties. Regulators adopt a purposive, teleological and consequentialist mode of reasoning. Moreover, they do not necessarily consider themselves bound by precedent; rather each case may be decided on its merits. ${ }^{89}$

\footnotetext{
${ }^{85}$ For discussion see J. Black, 'Regulatory Conversations' (2002) $29 \mathrm{Jnl}$ Law and Society 163.

${ }^{86}$ B. Jackson, Law, Fact and Narrative Coherence (Merseyside: Deborah Charles, 1988), 29-31.

${ }^{87}$ B. Jackson, Semiotics and Legal Theory (London: Routledge Kegan Paul, 1985) 41-43, 306-308; Y. Maley, 'The Language of the Law' and V. Bhatia, 'Cognitive Structuring in Legislative Provisions' in G. Gibbons (ed); Language and the Law (London: Longman, 1994); P. Goodrich, Reading the Law (Oxford: Blackwell, 1986) 105-121.

${ }^{88}$ Goodrich, ibid, 123-4.

89 When talking of a 'regulatory mode' here I'm constructing a Weberian ideal type - clearly not all regulators adopt this mode, and some lawyers in private practice do so with ease, and moreover as many regulators are lawyers the two social groups overlap. But the point is to characterize particular modes of reasoning.
} 
Each of these elements of regulatory reasoning and interpretation is an anathema to a lawyer. This is not to say they cannot engage in it: law firms have built lucrative businesses advising firms on how regulators will or will not respond in different situations. But it is rather that it is contrary to their training and one which some at least resist. In Luhmann's terms, the problem lawyers may have with regulatory interpretations of principles is principally that the 'programme' used by regulators for applying law is not one that they recognize ${ }^{90}$ - hence, their heavy criticism of PBR and all who sail in her. How many times do we hear it said in relation to the FSA's principles based approach that managers like PBR; but lawyers and compliance do not. This resistance may be because PBR exposes lawyers and requires them to make judgements about what will constitute compliance (be lawful) and what will not. This vulnerability may lie at the root of some of the resistance, and may be exacerbated in particular organizational structures where heavy blame may be placed on those who turn out to have made the wrong call. But lawyers are frequently asked to advise on matters where the application of the law is uncertain; so why should uncertainty itself pose such an issue?

The answer, at least in part, it is suggested, is twofold. First, albeit at the risk of caricature, PBR introduces an uncertainty which is of a different nature to that which lawyers encounter when considering how courts will interpret contractual terms. Lawyers are used to uncertainty, but the canons of legal interpretation are well understood. They do not eliminate uncertainty, but lawyers can hope to minimize it through their legal drafting. However, the regulatory interpretive approach is far less constrained by canons of interpretation built up over centuries and communicated through legal education and practice. As a result, for some participants at least, PBR does not facilitate communication but impedes it. However, the second reason for the concern over the uncertainty of PBR lies less in the niceties of interpretive practices, and more in the political acceptability of regulators. The debate on the uncertainty of principles, at least where the principles are being primarily enforced by a regulator, is at base often a political debate on the appropriate role of the regulator and / or any associated tribunal, rather than on interpretive practices per se, just as, as noted above, the debates on the practices of judicial interpretation are debates on the role of the judges. ${ }^{91}$ However lawyers may not be so opposed to the idea of a principles based regime if it were enforced by the courts, though regulators or senior management would be.

\footnotetext{
90 On programmes for applying the legal code see N. Luhmann, Social Systems (Stanford: Stanford UP, 1995.

${ }^{91}$ On the complexities of lawyers' responses to the New Deal see R. Shamir, Managing Legal Uncertainty: Elite Lawyers in the New Deal (Durham, NC: Duke University Press, 1995).
} 
PARADOX 3: THE COMPLIANCE PARADOX: PRINCIPLES PROVIDE SCOPE FOR FLEXIBILITY IN COMPLIANCE YET CAN LEAD TO CONSERVATIVE AND / OR UNIFORM BEHAVIOUR BY REGULATED FIRMS

Principles can provide flexibility for regulatees as to how they reach the outcome that is expressed by the Principle. However uncertainty as to the interpretation of principles that enforcers will adopt can result in firms adopting conservative behaviour, as if they were bound by detailed rules. This paradox is Schwarz's 'principles paradox': that principles in practice operate in a manner akin to that prompted by detailed rules. ${ }^{92}$ Schwarz's examples are drawn from common law contexts, where the courts are the arbiters of interpretation, but there is no reason that the paradox is avoided if the principles are applied by regulators, indeed the second paradox of principles (the communicative paradox outlined above) suggests that it may be exacerbated.

In this third paradox, which we may term the compliance paradox, compliance may be either uniform or conservative or both. So although PBR provides flexibility in modes of compliance, in practice firms' systems may be quite homogenous. This may arise because the regulator only accepts certain practices as complying; or because firms treat guidance on practices as if it were detailed rules. But even where neither of these conditions obtain, close similarity can still arise, particularly where PBR is polycentric or networked. In polycentric PBR, the practices of different firms are diffused (anonymously) throughout the industry through consultants and advisors. In sociological terms, institutional isomorphism is transmitted and mediated through these actors. There is no doubt that TCF has brought considerable business for consultancy firms, ranging from Deloittes and $\mathrm{PwC}$ to smaller, industry specialists and training firms, and to law firms as well. Indeed there is anecdotal evidence that TCF has prompted an 'arms race' between financial institutions, each 'tooling up' with the latest, and most costly, compliance models that consultants can provide.

Although there is as yet no detailed research on the implementation of TCF within firms, it is reasonable to suggest that the role of consultants can be acting as a force for convergence on a set of broadly common practices. The fairly substantial consultancy industry which has grown up around the TCF initiative is characterized by a comparatively small group of consultants plying their wares to firms keen to develop systems that can demonstrate their TCF compliance. ${ }^{93}$ As noted above, the effect of consultants in producing isomorphism - the development of similar systems and structures in a range of organizations - has been noted in different contexts by others. Power, for example, illustrates how

\footnotetext{
92 n 16 above.

93 A quick internet search reveals a number of advertisements for 'practical user friendly guidance' on TCF; 'top tips'; services in which firms will externally verify a firm's TCF compliance and tailored MI systems to capture data on customer focus and communication on performance progress from firms such as Deloittes, PwC, Brunswick MCL Ltd, Frank Eve Consulting; and training on TCF from the IFS School of Finance.
} 
the role of consultants in reconstructing the conceptual architecture of risk management and exploiting opportunities arising from the perceived need for change led to the development and diffusion of risk management practices in areas ranging from corporate governance to the definition and management of operational risk. ${ }^{94}$ Consultants ensure easy diffusion of their models by abstracting from specific practices, framing management issues in process terms which can then be aligned with the broader values being espoused, for example of corporate governance. ${ }^{95}$ Power uses the example of COSO to show how consultants effectively adapted the risk based model for internal controls proposed by COSO in 1991 and disseminated it to such a degree that it became the defining method for risk management in both private sector and public sector organisations. $^{96}$ In the regulatory context, Braithwaite and Drahos show how consultants act as 'model mercenaries', touting their wares to different regulators, who then either picked them up and used them unmodified (model misers) or in refined form (model mongers), resulting in a noticeably homogenised approach to defining and addressing regulatory problems. ${ }^{97}$ The TCF process is providing a further example of how practices develop through the activities of consultants.

Thus it is not only through regulatory pronouncements and successive rounds of guidance that practices can become concretized but through the homogeneizing practices of consultants and advisors. Although the systems that consultants provide vary in their detail - each is after all trying to differentiate itself from the other - they are united in their fundamentals, for consultants also sell their products on the basis that their core elements are familiar. In this case they are united, as Power argues, by a combination of values of control, accountability and audit. Indeed, as he argues, it is in combining new solutions to deep seated fears with a conservation of deeper aspirations, values and world views that the purveyors of risk management practices ensure their dissemination. ${ }^{98}$

\section{PARADOX 4: THE SUPERVISORY AND ENFORCEMENT PARADOX: PRINCIPLES NEED ENFORCEMENT TO GIVE THEM CREDIBILITY BUT OVER-ENFORCEMENT CAN LEAD TO THEIR DEMISE}

The place of enforcement in a PBR regime was discussed above. If the enforcement regime is on the tough, punitive end of the spectrum, then PBR is likely to transform as firms seek the comfort of detailed rules. Principles can however provide significant flexibility for regulators in the way they monitor and enforce the regulatory regime. The TCF initiative is again an example of a

\footnotetext{
94 Power, n 32 above, 160 and discussion at 48-53.

95 On the relationship between abstraction and diffusion see D. Strang and J. Meyer, 'Institutional Conditions for Diffusion' (1993) 22 Theory and Society 22, 487-511.

96 Power, n 32 above. COSO is a framework produced by the Committee of Sponsoring Organisations of th e Treadway Committee published in 1991 (Internal Control - Integrated Framework) following a Congressional inquiry into fraudulent financial reporting.

97 J. Braithwaite and P. Drahos, Global Business Regulation (Oxford: Oxford University Press, 2000).

98 Power, n 32 above, 161.
} 
substantial change in supervisory strategies which has been facilitated by principles (though it pre-dated the FSA's self-characterised move to its 'more principlesbased approach). The close engagement with firm's internal systems and processes which the FSA has adopted as part of the TCF initiative is a significant development of compliance and inspection strategies. The FSA is also leveraging its position as the holder of aggregate information of practices in a range of firms by disseminating examples of good and poor practices to help firms change their systems and benchmark themselves against industry norms. ${ }^{99}$

However, although principles can facilitate this negotiated mode of compliance, in which meaning and application can be negotiated through iterated regulatory conversations, PBR is also commonly criticized for facilitating retrospective interpretations of the norms. In the pensions misselling scandal, for example, the SIB relied on the suitability and know your customer requirements (technically classified as rules in the SIB rule book but with the form of principles) to require firms to engage in the pensions review, notwithstanding that pensions had been missold for years prior to the review without any regulatory action having been taken. 100 The SIB was accused of retrospectivity, but it had the will, and to an extent the political backing, to withstand those criticisms and order the review nevertheless. However in a different political climate, or with a different, less robust attitude amongst the regulators' senior management, regulators may be wary of taking enforcement action against firms' conduct, even if it could be interpreted as a breach of the principle. This is particularly likely where firms argue that enforcement action would be retrospective as the regulator had not mentioned any problems with their conduct before.

The significance of political support for tough enforcement action stems from the moral ambiguity of much regulation. Regulation has long been described as the prohibition of conduct which is 'mala prohibita' not 'mala in se': wrong because it is prohibited, not wrong because it is inherently immoral or contrary to human rights. Hawkins has illustrated how this moral ambiguity can lead to regulators being reluctant to take formal enforcement action. ${ }^{101}$ However it should be emphasized that this reluctance is independent of the presence or absence of principles; the same has been said of regulators in other systems characterised by detailed rules, for example in Canadian securities regulation. ${ }^{102}$ PBR will not of itself turn 'soft' regulators into hard enforcers, but neither will detailed rules. On the other hand, regulators can 'toughen' their approach to

\footnotetext{
${ }^{99}$ See the TCF cluster reports, available at http://www.fsa.gov.uk/Pages/Doing/Regulated/tcf/cluster/ index.shtml.

100 J. Black and R. Nobles, 'Personal Pension Misselling: The Causes and Lessons of Regulatory Failure' (1998) 61 Modern Law Review 789.

101 K. Hawkins, Environment and Enforcement (Oxford: Oxford University Press, 1984).

102 There have been a number of reports criticising the lax enforcement of Canadian securities regulators; see for example P. Puri, Enforcement Effectiveness in the Canadian Capital Markets (Commissioned by the Capital Markets Institute, June 2005); P. Puri and M. Condon, 'The Role of Compliance in Securities Regulatory Enforcement' Canada Steps Up Research Study Commissioned by the Task Force to Modernize Securities Legislation in Canada, Toronto, 2006.
} 
enforcement and supervision independently of any changes in the rules or sanctions available. 103

However, regulators under a PBR system may be more prone to encounter what we may term the supervisory and enforcement paradox if there is little internal appetite or little external political support for strong enforcement action. ${ }^{104}$ Principles have to be enforced to give the regime some credibility, particularly in the face of criticisms that they signify a 'weak' regulatory regime. However, tough enforcement has its drawbacks. Its effect on principles was noted above. But it can raise hostility to the regulatory regime. This can be politically significant, irrespective of the effect it has on firms' behaviour. Parker, for example, argues that regulators can fall into a 'compliance trap' where tough enforcement action is contested by firms if regulators lack political support for the moral seriousness of the law they must enforce. In these circumstances, regulators prefer to avoid conflict by adopting a softer approach to enforcement. Parker's focus was on political support from the political institutions of the legislature and executive, but it is suggested that other sources of support can also be relevant notably from the media and from senior management and board members within the regulatory organization itself.

PBR is vulnerable to tough enforcement, but may also be particularly susceptible to the compliance trap. Principles, as noted, are open to a range of interpretations; in negotiating compliance with a principle, even more so than with a detailed rule, the regulator has to rely on the firm according to it an interpretive authority to determine the final meaning of the rule (even if in formal terms this authority may lie elsewhere, for example with the courts). In other words the regulator has to rely on the firm accepting that what the regulator says, goes. Firms, as we know, may contest this. For this reason, detailed rules have been found to be used more effectively than Principles to persuade recalcitrant or sceptical firms to comply. ${ }^{105}$ The conversation between official and firm is then not 'but this is what we (the regulator) thinks "a safe system of work" requires' but 'the rule says your fire doors have to be this size'. The scope for debate is clearly quite different; as is the relative certainty of the outcome of any enforcement action.

The enforcement paradox is thus that taking enforcement action on the basis of breach of the principles is necessary to maintain the credibility of the regime and to gain the benefits of principles, from the regulators and potentially broader stakeholders' viewpoint, but enforcement may be under- or over-provided. Enforcement action may be compromised if the regulator lacks political support needed to impose sanctions for a breach of a principle. On the other hand, a

103 An example is the change in APRA's approach to supervision and compliance post HIH, notwithstanding the absence of any legislative changes: see J. Black, 'Managing Regulatory Risks and Defining the Parameters of Blame: the Case of the Australian Prudential Regulation Authority' (2006) 28 Law and Policy 1.

${ }^{104}$ C. Parker. 'The Compliance Trap - The Moral Message in Regulatory Enforcement' (2006) 40(3) Law and Society Review 591.

105 Baldwin, n 54 above. 
highly punitive enforcement regime is likely to result in the transformation of PBR into a system of detailed rules.

\section{PARADOX 5: THE INTERNAL MANAGEMENT PARADOX: PBR CAN PROVIDE FLEXIBILITY FOR INTERNAL CONTROL SYSTEMS TO DEVELOP BUT CAN OVERLOAD THEM}

Just as different types of rules can help or hinder the supervision and compliance activities of regulators, they can help or hinder the activities of compliance officers and others charged with compliance functions, including 'gatekeepers' such as auditors and legal advisors. Detailed, precise rules can help discourage noncompliant behaviour: they can help regulators, compliance officers and gatekeepers say 'no' to firms, at least when the opportunities for creative compliance are not available or clients are unaware of the precise rules. ${ }^{106}$ Detailed rules can potentially be used more effectively than Principles to persuade recalcitrant or sceptical firms (or internal management) that they should change their behaviour. Detailed rules can thus empower supervisors, and indeed internal compliance officers, in certain circumstances, whereas Principles will not, as debates can always be had about their interpretation. ${ }^{107}$

Again, the issue of weak internal compliance cannot be itself resolved by the use of detailed rules. Having detailed rules does not mean that internal compliance is more effective; indeed the extensive studies which have been done of internal compliance find the form of the rules within the regulatory regime irrelevant to the development of effective internal compliance systems. ${ }^{108}$

So whether there are principles or detailed rules does not of itself mean internal compliance will be strong or weak. However PBR puts a different type of strain on compliance systems than a system of detailed rules. One consequence of moving to a more principles-based approach is that compliance is called upon to make more judgements as to what has to be done in order to comply. This has been increasingly well recognized by the FSA. In its April 2007 paper, the FSA emphasized the changing role for compliance that the move to PBR entailed. ${ }^{109}$ The compliance function becomes central, and requires a different mind set and skill set from that required to ensure compliance with detailed rules - from box ticking to exercises of judgement and the development of strategic vision.

PBR can, in this respect, empower compliance functions, but arguably only if they are already strong within the organisation. There is evidence that many compliance functions are not ready to take on this role, however. As a result, PBR may not stimulate and strengthen those functions but will rather overload them.

\footnotetext{
106 M.W. Nelson, "Behavioural Evidence on the Effects of Principles- and Rules-Based Standards" (2003) 17 (1) American Accounting Association 91.

107 ibid for examples.

108 At least implicitly, for they never figure in the discussions. For review and discussion see Parker, n 32 above.

109 FSA, PBR, 17-18.
} 
A recent survey by $\mathrm{PwC}$, Protecting the Brand, found that $30 \%$ of financial institutions stated that their boards' incomplete acceptance or understanding of the role of compliance was a significant hurdle to achieving compliance. ${ }^{110}$ Moreover, over $40 \%$ of financial institutions said that their systems for managing operational risk, including compliance and legal risk, were significantly more underdeveloped than their systems for managing quantitative risks such as market or credit risk. Thus PBR, at least full PBR, is fundamentally reliant on the development of sophisticated and judgement-based compliance systems. It can enhance the role of those that are already strong, but at the same time may overload functions which are already underdeveloped and in a relatively weak position within their own firms: the internal management paradox.

\section{PARADOX 6: THE ETHICAL PARADOX: PBR CAN FACILITATE A MORE ETHICAL APPROACH BUT IT COULD RESULT IN AN EROSION OF ETHICS}

The ethical paradox lies partly in full PBR itself and partly in its co-junction with risk management strategies within firms on the one hand, and with risk based approaches to supervision by the regulator on the other. The ethical paradox is that PBR can enhance the role of ethics in business decisions, but in requiring firms to make a judgement on what they have to do to comply, PBR requires firms to run the risk that they may make the wrong call. PBR thus requires compliance to become risk managers - in this case managers of interpretive risk, the risk of a wrong interpretation, and any associated risk to the firm stemming from enforcement action, such as financial loss or reputational damage. But when compliance becomes a matter of risk management, non-compliance becomes an option. In becoming risk managers, compliance personnel have to accept that there is a risk of non-compliance. Someone within the firm then has to assess whether the level of risk in any particular instance is one the firm is prepared to run. .Indeed, performing risk / cost trade offs with respect to compliance is advocated by leading consulting firms as a key stage in the compliance risk management process. Firms are told to decide on the regulatory outcomes that they wish to deliver, and the risk / cost trade off in doing so ${ }^{111}$. In other words, they should assess what level of non-compliance they are prepared to risk, and what the potential cost of enforcement action and reputational damage may be of (detected) non-compliance. Firms are warned that adopting a low appetite for compliance risk could mean that the firm ends up with an internal compliance manual which is longer than the FSA's rule book. ${ }^{112}$ The FSA is itself urging firms to take a 'risk based approach' to compliance in certain areas, notably money

\footnotetext{
${ }^{110}$ PwC, Protecting the Brand.

111 E.g. Deloitte, Principles Based Regulation: What Firms Need to do Now (July 2007) available at http://www.deloitte.com/dtt/cda/doc/content/UK_FS_PrinciplesBasedRegulation.pdf (accessed 18th June 2008). See also A. Whittaker, 'Lawyers as Risk Managers' (2003) 18(1) BJIBFL 5 (Andrew Whittaker is the FSA's General Counsel).

112 ibid.
} 
laundering, and under the TCF initiative, where firms have been advised to adopt a risk based approach to the compliance monitoring of their sales advisors. ${ }^{113}$

The potential ethical paradox is thus that PBR can facilitate the development of ethical approaches to compliance, but the greater interpretive risk that it imposes on firms can mean that ethics become compromised. To reiterate, interpretive risk is the risk that their interpretation and application of the principles will not be approved by the regulator. To the extent that compliance is associated in practice within firms with risk management methodologies, as it increasingly is in financial firms, ${ }^{114}$ this may run counter to one of the potential advantages of PBR, which is its ability to foster a more ethical culture within firms. For one of the potential positive effects of PBR is to prevent game playing and thus foster an approach which seeks, if not to 'go beyond' compliance, at least to go beyond minimal compliance. In other words, to develop a responsible and ethical culture focused on achieving certain outcomes. Yet there is a significant argument that risk management approaches effectively kill ethics, for two reasons. First, they mechanise them, reducing them to processes to be followed rather than judgements to be made. Secondly in making non-compliance an option, the decision of what to do becomes based on whether or not one will be caught for non-compliance and if so, whether the firm can manage the consequences in such a way as to minimize the reputational or financial damage that may result.

There is a growing body of literature on ethics and risk management within law firms, for example, which argues that risk management systems imperil lawyers' ethical judgement and moral reasoning. ${ }^{115}$ When lawyers become risk managers, they approach the task of managing compliance risks with noncompliance as a viable option. ${ }^{116}$ The phenomenon is not necessarily confined to lawyers. Rosen, writing about the role of auditors in Enron, argued that 'as compliance decisions are understood as risk management decisions, serious conflicts of interest emerge between the normative idea of auditors and the reality of their business, in which compliance partners sell risky compliance'. ${ }^{117}$ Risk management systems themselves are sold on the rhetoric of opportunity, enterprise and value creation. ${ }^{118}$ When based on assessments of risk, compliance decisions are no longer based on a wider consideration of what would be the course of action that would best uphold the relevant principles of conduct in the circumstances. In other words, in deciding on a course of action, the question that

113 FSA, Quality of Advice Process in Firms Offering Financial Advice: Considerations for Treating Customers Fairly (FSA, July 2006)

114 And indeed as it is required to be within banks and EU insurance companies under the Basle II and Solvency II regimes.

115 A useful review is provided by A. Alfieri, 'The Fall of Legal Ethics and the Rise of Risk Management' (2008) 93(5) Georgetown Law Jnl 1; for a more optimistic picture however see C. Parker. 'The Ethics of Advising on Regulatory Compliance: Autonomy or Interdepencence?’ (2000) Jnl Business Ethics 339.

116 R. Rosen, "We're All Consultants Now": How Change in Client Organizational Strategies Influences Change in the Organization of Corporate Legal Services’ (2002) 44 Ariz. L. Rev. 637, 638.

117 R. Rosen, Risk Management and Organizational Governance: The Case of Enron (2003) 35 Conn. L. Rev. 1157, 1180, also available at http://papers.ssrn.com/sol3/papers.cfm?abstract_id=468168, 1180.

118 Power, n 32 above, 23. 
is asked is not 'is this the right thing to do?' but instead, 'are we likely to be able to get away with it?'

Can using detailed rules avoid this paradox? It does not appear so. The debate on the tension between ethics and risk management occurs in regimes in which there are detailed rules as well as those in which there are principles. Yet although this phenomenon is not unique to PBR regimes, it may be enhanced by them, though whether and how it does is still unclear. Under a PBR regime, there becomes greater reliance on the compliance and / or legal divisions to make judgement calls, and because of uncertainties surrounding the interpretation and enforcement of the principles, the risks of being found to be non-compliant may be higher. The question then is who takes the decision to take this risk (assuming that a conscious decision is made)? Frequently compliance and / or legal divisions argue that it is not they that 'own' the risk of non-compliance but the business. They can advise on the likely outcome under the regulatory regime, but it is for the business to determine whether or not it wants to take this course of action or not. Whether or not 'ownership' of the risk can really be displaced in this way is a moot point. But the issue here is that in this situation, the more that lawyers or compliance managers take this approach to 'ownership' of that liability risk, the more they shift responsibility for normative and ethical judgements to others within the firm. As Regan has argued, this shifting of ownership can induce a kind of moral apathy, where the responsibility is taken by noone. ${ }^{119}$

The combination of PBR and risk management may thus have the effect, at the very least, of neutralizing the ethical dimension of principles based regulation if not negating it. Whether the purposive nature of principles, combined with the other dimensions of substantive PBR, means that PBR can withstand these effects remains to be seen.

\section{PARADOX 7: THE TRUST PARADOX - PBR CAN GIVE RISE TO RELATIONSHIPS OF TRUST, MUTUALITY AND RESPONSIBILITY BUT THESE ARE THE VERY RELATIONSHIPS WHICH HAVE TO EXIST FOR IT TO BE EFFECTIVE}

The Utopian vision invoked by PBR outlined above is one in which the regulatory compact between the regulator and the regulated is re-framed. The relationship moves from one of directing and controlling to one based on responsibility, mutuality and trust. Regulators and regulatees move from a directing relationship of telling and doing, to a relationship in which regulators communicate their goals and expectations clearly in principles and apply those principles predictably, regulatees adopt a self-reflective approach to the development of processes and practices to ensure that these goals are substantively met, and, critically, both trust each other to fulfil their side of this new regulatory bargain.

The trust paradox is that there has to be a high level of trust between all the participants in the regulatory regime for PBR, in both its formal and substantive

119 See also Alfieri, n 114 above, 27; Milton C. Regan, Jr., 'Risky Business' (2006) 93 Georgetown LJ 8. 
forms, to operate at all. PBR can help this relationship develop; but it needs it to exist before PBR can even begin to work. The final paradox is possibly the ultimate paradox of PBR. PBR is based on trust that it alone cannot create, though it can facilitate its development. Trust in turn can help to resolve many of the paradoxes identified above. Without trust, PBR will never be operationalised; it will exist only in the text of the rule books, not in the way they are implemented.

\section{SUMMARY AND CONCLUSIONS}

PBR is thus a highly complex form of regulation, belying its rhetoric of simplicity. Its attractiveness to politicians lies in its malleability and in the vision it evokes; for academics it accords with all the messages of the 'new governance' paradigm(s). The rhetoric of PBR masks, or deliberately confuses, its various forms. PBR can exist in form only; can exist in substance without the form; or where both are present can exist in its full form. Moreover, PBR may be polycentric where a range of actors other than the regulator and regulated firm are enrolled in the production of meanings and interpretations.

However PBR in its various forms is beset with a number of paradoxes, some of which are inherent within it, some of which arise from its juxtaposition or association with other practices, such as risk management. Delineating the nature of these paradoxes both within financial services regulation and in other regulatory regimes which could be characterized as PBR regimes requires further investigation. However, in delineating the different forms of PBR and identifying its paradoxes, this paper hopes to move the debate on both from the sweeping rhetoric of the political debates and the relatively stagnated policy and academic debate on advantages and disadvantages of principles over detailed rules. PBR, in its full form, can provide an effective, durable, resilient and goal based regulatory regime; but at the same time its paradoxical nature means that it is vulnerable. However, as many of these paradoxes are not necessarily avoided by using detailed rules instead of principles, it is only through recognizing and exploring the dynamics of these paradoxes that we can be fully aware of the potentials and limitations of the use of rules in any regulatory regime, whether it is principlesbased or not. But the ultimate paradox is that which can hold the key to resolving many of the others, but which is the hardest itself to resolve. It is that PBR can help create trust, but it itself has to be founded on trust if it is ever to operate effectively, if indeed at all. 